\title{
Evaluation of tumor biomarkers and cytokines in the detection and follow up of colorectal cancer
}

\author{
Nada A. Hasso ${ }^{a}$, Zainalabideen A. Abdulla ${ }^{b}$ \\ From the Department of Microbiology, ${ }^{a}$ Nineveh college of Medicine, ${ }^{b}$ College of Medicine, University of Mosul, Mosul, Iraq. \\ Correspondence: Nada A. Hasso ${ }^{\text {. }}$.dr.nada_alhasso@yahoo.com. \\ (Ann Coll Med Mosul 2013; 39 (2): 172-177). \\ Received: $18^{\text {th }}$ Mar. 2013; Accepted: 31 ${ }^{\text {th }}$ Oct. 2013.
}

\section{ABSTRACT}

Objectives: To use a panel of seven tumor markers for the detection and follow up of colorectal cancer. To compare the diagnostic utility of the tumor markers with that of the standard methods. To construct ROC curve for the purpose of the best detection of the studied cancer.

Patients and methods: Fifty two colorectal cancer patients and 30 apparently healthy individuals as a control group were studied. They were tested for: carcinoembryonic antigen (CEA), cancer antigen 19-9, cancer antigen 72-4 and tissue polypeptide antigen (TPA), two cytokines [interleukin-6 (IL-6)] and vascular endothelial growth factor (VEGF)] by using ELISA. Twenty colorectal cancer patients were followed up for a period of 3-5 months after surgical resection.

Results: There was a significant difference $(p<0.001)$ in the diagnostic utility between cancer and control group for all the seven tumor markers. In colorectal cancer group, a significant difference $(p<0.001)$ in the serum concentration of CEA, TPA, IL-6, VEGF and CRP was detected according to the stage of cancer. No significant difference was shown for CA 19-9 and CA 72-4. Using ROC curve analysis, CEA was the best diagnostic test. In the follow up group, a significant reduction was found for all the seven investigated parameters.

Conclusion: CEA, CA 19-9, CA 72-4, TPA, IL-6, VEGF and CRP are of considerable diagnostic, prognostic and follow up utility. ROC curve is used to enhance the diagnostic accuracy of the studied tumor markers.

Keywords: Colorectal cancer, tumor biomarker, interleukin-6, vascular endothelial growth factor.

\section{تقييم معلمات الأورام ومفعلاث الخلايا في إكتثاف ومتابعة سرطانات الجهاز الهضمي

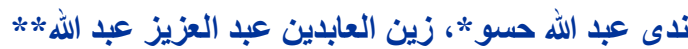 \\ فرع الاحياء المجهرية، *كلية طب نينوى، **كلية الطب، جامعة الموصل، الموصل، العراق}

الأهداف: إستخدام مجموعة تتضمن سبع من معلّمات الأورام في كثف ومتابعة حالات سرطانات القولون و المستقيم، ومقارنة الفائدة التشخيصية لمعلمات الأورام مع الطرق الروتينية والقياسية، مع وضع خط بياني نوع ROC ، من من أجل الكثف الأفضل لهذه

المرضى وطرائق العمل: تضمت مجموعة المرضى Or مصابا بسرطان القولون والمستقيم بالإضافة إلى •r شخصا سليما

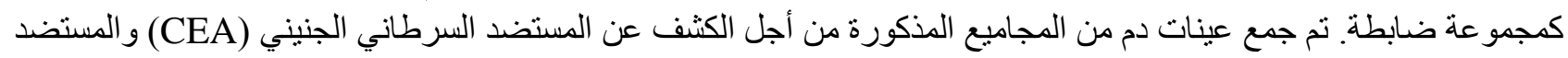

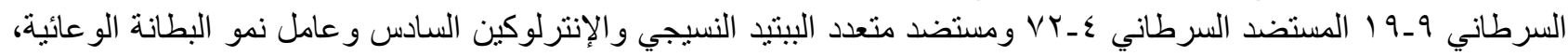

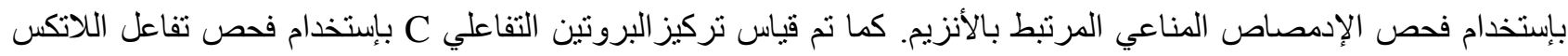

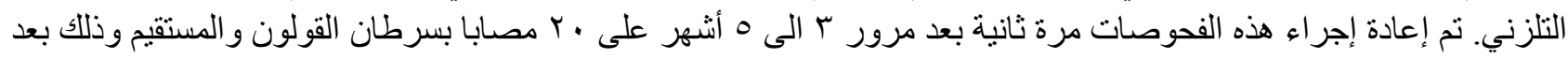
إستئصال الورم لهم. النتائج: أظهرت النتائج وجود فرق معنوي في الفائدة التشخيصية لكافة معلمات الأورام المستخدمة لدى المرضى مقارنة

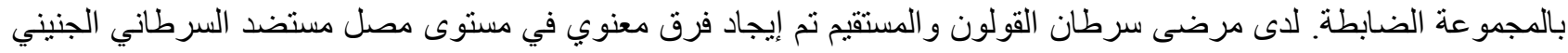

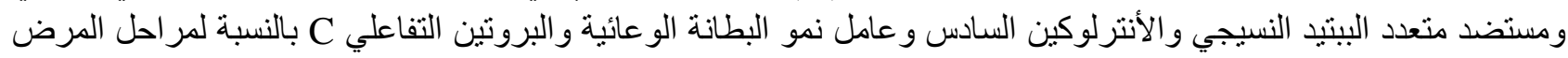

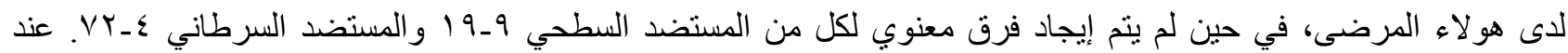

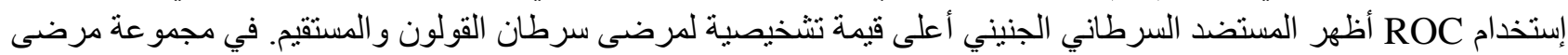

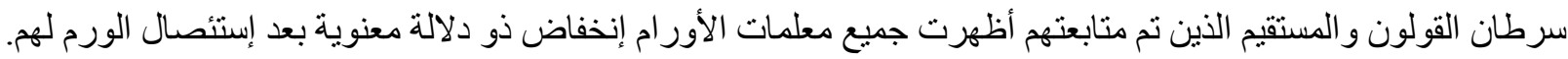




$$
\begin{aligned}
& \text { الإستنتاجات: إن جميع معلّمات الأورام التي قيست في هذه الدراسة ذات فائدة ملحوظة في التشخيص و التنبؤ ومتابعة مرضى ئنس }
\end{aligned}
$$

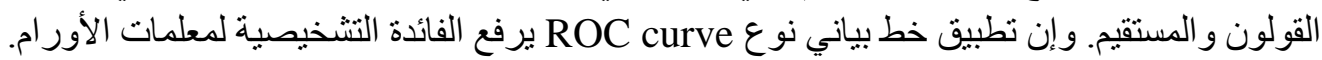

\section{INTRODUCTION}

C ancers of colon and rectum represent more than $15 \%$ of all cancers worldwide. ${ }^{1}$ Colorectal cancer is the second most common cause of cancer-related death in Western countries after lung cancer in men and breast cancer in women. ${ }^{2}$ Carcinoma of the colon was ranked as the sixth cancer among the top ten cancers in Mosul. ${ }^{3}$ Identification of cancer biomarkers is one of the most promising approaches for the detection of early stage malignant or even pre-malignant lesion with a simple blood test. ${ }^{4}$ As there is no ideal tumor marker, the usage of a panel with two or more approved markers can contribute to the improvement in sensitivity and diagnostic efficacy. ${ }^{5}$ Carcinoembryonic antigen (CEA) is a complex glycoprotein that is associated with the plasma membrane of tumor cells from which it may be released into the blood. ${ }^{6}$

Cancer antigen 19-9 is an example of type 1 terminal carbohydrate structure and plays an important role in cell adhesion and local tumor invasiveness and metastasis. ${ }^{7}$ Cancer antigen 72 4 is a high molecular weight mucin glycoprotein detectable in the sera of patients with a variety of gastrointestinal adenocarcinomas. ${ }^{8}$ Tissue polypeptide antigen is a complex of polypeptide filaments of the cytokeratin 8,18 and 19 . It represents the most abundant cytokeratin pattern in malignant epithelial differentiation. ${ }^{9}$ Interleukin-6 is a potent pleiotropic inflammatory cytokine that causes carcinogenesis through several signal pathways involved in carcinogenesis and metastasis. ${ }^{10}$ Vascular endothelial growth factor is overexpressed by the majority of solid human tumors, where it can be produced by the tumor cells themselves or by stromal cells. ${ }^{11}$ The importance of the serum elevation of CRP in the tumorigenesis and pathogenesis of some cancers such as colorectal cancer has become a focus of much attention. ${ }^{12}$

\section{PATIENTS AND METHODS}

This case-control study was conducted between $1^{\text {st }}$ April 2008 and $30^{\text {th }}$ April 2009. The patients were recruited mainly from the Endoscopic Units in AlJamhuri and Ibn Sina Teaching Hospitals, Surgical
Wards in Al-Jamhuri Teaching Hospital and from Oncology and Nuclear Medicine Hospital. A total of 82 patients were included, 52 were colorectal cancer patients and 30 were apparently healthy individuals as a control group. The patients were clinically and histologically verified as colorectal carcinoma with age range of $26-75$ years. The cases comprised 25 males and 27 females. Twenty of the 52 patients were followed up postoperatively for a period of 3-5 months. Peripheral blood samples were obtained from the patients pre-operatively. All sera were aliquoted and kept frozen at $-20^{\circ} \mathrm{C}$ until use. The CEA, CA 19-9, CA 72-4, TPA, IL-6 and VEGF were measured by using solid phase ELISA kits supplied by DRG instruments $\mathrm{GmbH}$, Germany. The CRP was measured using a CRP latex test kit supplied by Plasmatec, UK.

Statistical Analyses: Statistical analyses were computer assisted using SPSS VERSION 10. Paired, unpaired t-tests and Chi-square were used for all the dual comparisons. All the statistical results were considered significant at $p$ equal to 0.05 or less. $^{13}$

\section{RESULTS}

The mean serum levels of CEA, CA 19-9, CA 72-4, TPA, IL-6 and VEGF preoperatively were significantly higher $(p=0.001)$ in patients with colorectal cancer than in the control group Table 1. The frequencies of levels of $\leq 6 \mathrm{mg} / \mathrm{L}$ in the control group was significantly higher $(p<0.001)$ than in the colorectal cancer patients and vice versa for levels $>12 \mathrm{mg} / \mathrm{L}$ up to $192 \mathrm{mg} / \mathrm{L}$ Table 2 . The mean serum level of CEA, CA19-9, TPA, IL-6 and VEGF were the highest among patients with modified Dukes D stage Table 3 with significant difference $(p<0.001)$ between this stage and other stages $(p<0.001)$. For the serum tumor marker CA $72-4$, no significant difference was found. Patients with modified Dukes $D$ stage colorectal cancer showed a significant higher $(p<0.001)$ frequencies of CRP level of $48-192 \mathrm{mg} / \mathrm{L}$ than in patients with modified Dukes A, B and C Table 4. 
Table 1. Comparison of serum tumor markers between cases and control using unpaired $\mathrm{t}$ - test.

\begin{tabular}{|c|c|c|c|c|c|c|}
\hline Markers & Groups & $\mathbf{N}$ & Mean & SD & Range & $p$-value \\
\hline \multirow{2}{*}{ CEA (ng/ml) } & Control & 30 & 3.37 & 1.4 & $1-8$ & \multirow{2}{*}{$<0.001$} \\
\hline & Colorectal & 52 & 26.63 & 25.27 & $2.5-87$ & \\
\hline \multirow{2}{*}{ CA19-9 (U/ml) } & Control & 30 & 28.53 & 6.07 & $19-47$ & \multirow{2}{*}{$<0.001$} \\
\hline & Colorectal & 52 & 77.44 & 69.46 & $21-230$ & \\
\hline \multirow{2}{*}{ CA72-4 (U/ml) } & Control & 30 & 3.47 & 1.11 & $1-5$ & \multirow{2}{*}{0.001} \\
\hline & Colorectal & 52 & 12.78 & 16.69 & 1.5- 61 & \\
\hline \multirow{2}{*}{ TPA (ng/ml) } & Control & 30 & 0.92 & 0.50 & $0.1-2$ & \multirow{2}{*}{$<0.001$} \\
\hline & Colorectal & 52 & 10.07 & 12.2 & $0.2-52$ & \\
\hline \multirow{2}{*}{ IL-6 (pg/ml) } & Control & 30 & 7.37 & 2.72 & $4-18$ & \multirow{2}{*}{0.001} \\
\hline & Colorectal & 52 & 39.56 & 48.81 & $4-187$ & \\
\hline \multirow{2}{*}{ VEGF (pg/ml) } & Control & 30 & 166.47 & 148.3 & 50 & \multirow{2}{*}{$<0.001$} \\
\hline & Colorectal & 52 & 721.06 & 665.1 & 50 & \\
\hline
\end{tabular}

Table 2. CRP for patients and control.

\begin{tabular}{|c|c|c|c|c|c|}
\hline \multirow{2}{*}{$\begin{array}{c}\text { Group } \\
\text { CRP (mg/L) }\end{array}$} & \multicolumn{2}{|c|}{ Control } & \multicolumn{2}{|c|}{ Colorectal } & \multirow{2}{*}{$p$-value } \\
\hline & No. & $\%$ & No. & $\%$ & \\
\hline$<6$ & 24 & 80.0 & 18 & 34.6 & \multirow{7}{*}{$<0.001$} \\
\hline 6 & 3 & 10.0 & 1 & 1.9 & \\
\hline 12 & 2 & 6.7 & 3 & 5.8 & \\
\hline 24 & 1 & 3.3 & 9 & 17.3 & \\
\hline 48 & 0 & 0.0 & 13 & 25.0 & \\
\hline 96 & 0 & 0.0 & 7 & 13.5 & \\
\hline 192 & 0 & 0.0 & 1 & 1.9 & \\
\hline Total & 30 & 100 & 52 & 100 & \\
\hline
\end{tabular}

Using Fisher Freeman Halton test.

Table 3. Relationship between measured tumor markers and stage of colorectal cancer.

\begin{tabular}{|c|c|c|c|c|c|c|}
\hline Parameters & Stage & No & Mean & SD & Range & $p$-value \\
\hline \multirow{4}{*}{ CEA (ng/ml) } & $A$ & 2 & $3.50 \mathrm{a}$ & 0.71 & 3- 4 & \multirow{4}{*}{$<0.001^{*}$} \\
\hline & B & 19 & $9.43 \mathrm{a}$ & 8.99 & $2.5-28$ & \\
\hline & C & 23 & $25.71 b$ & 14.55 & 3- 46 & \\
\hline & D & 8 & 75.88 c & 6.88 & $68-87$ & \\
\hline \multirow{4}{*}{ CA19-9 (U/ml) } & A & 2 & $26.50 \mathrm{a}$ & 0.71 & $26-27$ & \multirow{4}{*}{$\begin{array}{c}<0.05^{*} \\
0.094 \text { (NS) }\end{array}$} \\
\hline & B & 19 & $80.2 \mathrm{ab}$ & 60.68 & 21-185 & \\
\hline & C & 23 & $62.3 \mathrm{ab}$ & 58.92 & 25- 198 & \\
\hline & D & 8 & $127.13 b$ & 102.17 & $29-230$ & \\
\hline \multirow{4}{*}{ CA $72-4(\mathrm{U} / \mathrm{ml})$} & A & 2 & $3.55 \mathrm{a}$ & 0.92 & $2.9-4.2$ & \multirow{4}{*}{$\begin{array}{c}<0.05^{*} \\
0.355 \text { (NS) }\end{array}$} \\
\hline & B & 19 & $8.48 \mathrm{a}$ & 10.05 & $1.5-39$ & \\
\hline & C & 23 & $16.93 \mathrm{~b}$ & 20.05 & $2-61$ & \\
\hline & $\mathrm{D}$ & 8 & $13.38 a b$ & 19.33 & $3-58$ & \\
\hline \multirow{4}{*}{ TPA (ng/ml) } & A & 2 & $4.30 \mathrm{a}$ & 1.84 & $3-5.6$ & \multirow{4}{*}{$<0.001^{*}$} \\
\hline & B & 19 & $5.22 \mathrm{a}$ & 6.22 & $0.2-22$ & \\
\hline & C & 23 & $8.58 \mathrm{a}$ & 8.12 & $0.2-25$ & \\
\hline & $\mathrm{D}$ & 8 & $27.31 \mathrm{~b}$ & 18.89 & $0.2-52$ & \\
\hline \multirow{4}{*}{ IL-6 (pg/ml) } & A & 2 & $8.00 \mathrm{a}$ & 1.41 & $7-9$ & \multirow{4}{*}{$<0.001^{*}$} \\
\hline & B & 19 & $13.42 \mathrm{a}$ & 8.7 & 4- 33 & \\
\hline & C & 23 & 28.57 a & 24.03 & 4- 78 & \\
\hline & $\mathrm{D}$ & 8 & $141.13 b$ & 32 & $100-187$ & \\
\hline \multirow{4}{*}{ VEGF (pg/ml) } & A & 2 & $65.00 \mathrm{a}$ & 21.21 & $50-80$ & \multirow{4}{*}{$<0.001^{*}$} \\
\hline & B & 19 & $390.8 \mathrm{ab}$ & 322.52 & $50-920$ & \\
\hline & C & 23 & $627.83 \mathrm{~b}$ & 507.96 & $50-2000$ & \\
\hline & $\mathrm{D}$ & 8 & 1937.5 c & 74.4 & 1800- 2000 & \\
\hline
\end{tabular}


Table 4. CRP and colorectal cancer stage*.

\begin{tabular}{|c|c|c|c|c|c|c|c|c|c|}
\hline \multirow{2}{*}{$\begin{array}{c}\text { Stage } \\
\text { CRP (mg/L) }\end{array}$} & \multicolumn{2}{|c|}{$\mathbf{A}$} & \multicolumn{2}{|c|}{ B } & \multicolumn{2}{|c|}{ C } & \multicolumn{2}{|c|}{ D } & \multirow{2}{*}{$p$-value } \\
\hline & No. & $\%$ & No. & $\%$ & No. & $\%$ & No. & $\%$ & \\
\hline$<6$ & 2 & 100 & 10 & 52.6 & 6 & 26.2 & 0 & 0.0 & \multirow{7}{*}{$<0.001$} \\
\hline 6 & 0 & 0.0 & 0 & 0.0 & 1 & 4.3 & 0 & 0.0 & \\
\hline 12 & 0 & 0.0 & 2 & 10.5 & 1 & 4.3 & 0 & 0.0 & \\
\hline 24 & 0 & 0.0 & 5 & 26.4 & 4 & 17.4 & 0 & 0.0 & \\
\hline 48 & 0 & 0.0 & 2 & 10.5 & 7 & 30.4 & 4 & 50.0 & \\
\hline 96 & 0 & 0.0 & 0 & 0.0 & 4 & 17.4 & 3 & 37.5 & \\
\hline 192 & 0 & 0.0 & 0 & 0.0 & 0 & 0.0 & 1 & 12.5 & \\
\hline Total & 2 & 100 & 19 & 10 & 23 & 100 & 8 & 100 & \\
\hline
\end{tabular}

Using Fisher Freeman Halton test.

$\mathrm{NS}=$ Not significant according to the analysis of variance (ANOVA), means with different letters vertically have significant difference at $\mathrm{p}<0.05$ for each marker.

In colorectal cancer patients: The ROC curve of CEA (red line) was the highest among other tumor markers curves (Figure 1). ROC area for the measured parameters for the diagnosis of colorectal cancer. CEA shows the highest area under the curve, closest to the optimal sensitivity and specificity (criterion $0,1.00$ ).

The twenty followed up patients showed a significant difference between the preoperative and postoperative mean values of the seven tumor markers (Table 5, 6).

Table 5. Comparison of the preoperative and postoperative means of serum tumor markers in the follow up colorectal cancer group.

\begin{tabular}{|c|c|c|c|c|}
\hline Markers & Period & Mean & SD & $\begin{array}{l}p \text { - } \\
\text { value }\end{array}$ \\
\hline \multirow{2}{*}{$\mathrm{CEA}(\mathrm{ng} / \mathrm{ml})$} & Preoperation & 23.1 & 22.97 & \multirow{2}{*}{0.018} \\
\hline & Postoperation & 14.41 & 14.08 & \\
\hline CA19-9 & Preoperation & 85.85 & 73.83 & \multirow{2}{*}{0.011} \\
\hline$(\mathrm{U} / \mathrm{ml})$ & Postoperation & 52.05 & 33.25 & \\
\hline \multirow{2}{*}{$\begin{array}{l}\text { CA72-4 } \\
(\mathrm{U} / \mathrm{ml})\end{array}$} & Preoperation & 11.11 & 15.2 & \multirow[b]{2}{*}{0.047} \\
\hline & Postoperation & 5.41 & 3.97 & \\
\hline \multirow{2}{*}{ TPA (ng/ml) } & Preoperation & 8.46 & 11.05 & \multirow{2}{*}{0.037} \\
\hline & Postoperation & 3.89 & 5.39 & \\
\hline \multirow{2}{*}{ IL-6( pg/ml) } & Preoperation & 27.5 & 36.09 & \multirow{2}{*}{0.041} \\
\hline & Postoperation & 12.88 & 15.1 & \\
\hline \multirow{2}{*}{$\begin{array}{l}\text { VEGF } \\
(\mathrm{pg} / \mathrm{ml})\end{array}$} & Preoperation & 698.5 & 659.92 & \multirow{2}{*}{0.001} \\
\hline & Postoperation & 338.2 & 302.93 & \\
\hline
\end{tabular}

Table 6. CRP frequency in the follow up colorectal cancer patients.

\begin{tabular}{|c|c|c|c|c|c|}
\hline \multirow{2}{*}{ CRP } & \multicolumn{2}{|c|}{ Pre operation } & \multicolumn{2}{|c|}{ Post operation } & \multirow{2}{*}{$\begin{array}{c}p- \\
\text { value }\end{array}$} \\
\hline & No. & $\%$ & No. & $\%$ & \\
\hline 0 & 5 & 25.0 & 4 & 20.0 & \multirow{6}{*}{0.026} \\
\hline 6 & 1 & 5.0 & 3 & 15.0 & \\
\hline 12 & 2 & 10.0 & 3 & 15.0 & \\
\hline 24 & 5 & 25.0 & 9 & 45.0 & \\
\hline 48 & 6 & 30.0 & 1 & 5.0 & \\
\hline 96 & 1 & 5.0 & 0 & 0.0 & \\
\hline Total & 20 & 100 & 20 & 100 & \\
\hline
\end{tabular}

Using Wilcoxon paired Z-test.

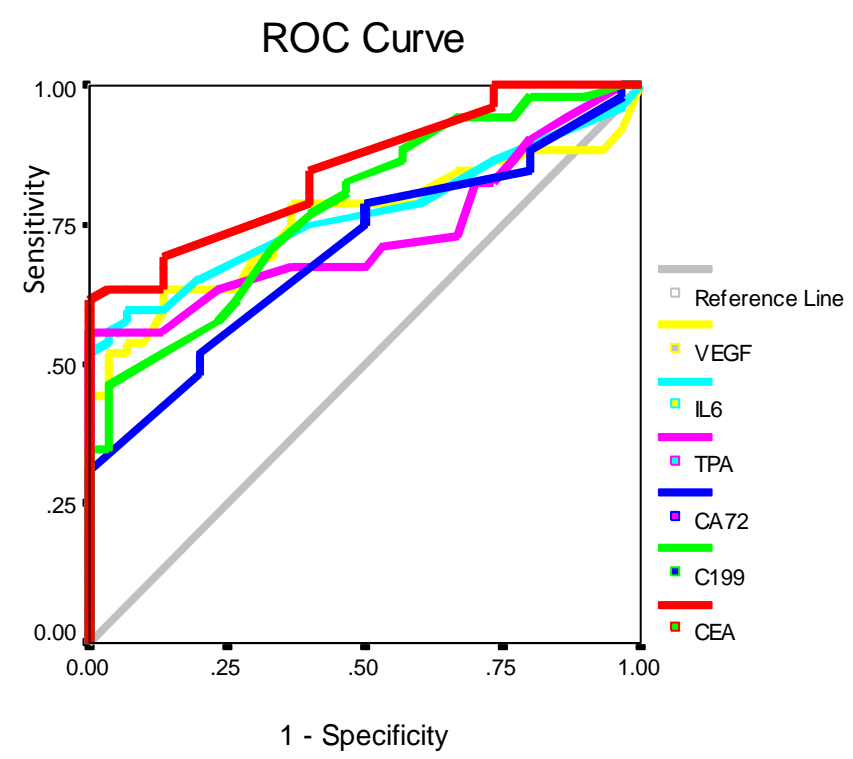

Fiqure 1.

\section{DISCUSSION}

Our results are in agreement with studies on colorectal cancer patients that also demonstrated significant higher serum levels of CEA in comparison with the control group. ${ }^{14,15}$ Carcinoembryonic antigen is an intracellular adhesion molecule that is up-regulated in colorectal cancer. $^{16}$ Our results were comparable with that of Meteoglu and Coworkers ${ }^{17}$ who found that serum CEA was correlated well with Dukes staging in colorectal cancer. The production of CEA by tumor cells has been described as a linear relationship between cell number and serum CEA. ${ }^{18}$ Significant higher levels of serum CA 19-9 in the cancer group patients compared to the control group were found, however, no significant correlation with staging of the disease was found.

Previous studies demonstrated that CA 19-9 was a sensitive tumor marker and its level increases as 
the disease spreads without significant relationship with tumor staging. ${ }^{19,20}$ The significant elevated serum concentration of CA 72-4 in cancer group compared to control group is due to increase expression of this tumor mucin antigen in cancer patients. In contrast, the non-significant difference in CA 72-4 serum level with regard to colorectal cancer staging noticed in the current study was also demonstrated by Phlebani and Coworkers. ${ }^{20}$ The mean serum level of TPA was found to be higher in cancer patients group than in the control group in the current study. These findings are due to the overexpression of TPA in proliferating malignant tumors. ${ }^{21}$ It was found that TPA is a sensitive test in determining the stage of colorectal neoplastic process according to modified Dukes staging. ${ }^{22}$

The results are comparable with others who found that the serum level of IL- 6 was significantly higher in cancer patients when compared to healthy subjects. ${ }^{23}$ The elevated IL- 6 may be due to its production by cancer cells and the other possibility is that IL-6 is produced as a result of immunologic response to cancer. ${ }^{24}$ Interleukin-6 levels have increased in a stage-related manner. Two studies showed a significant high concentration of IL- 6 in the advanced stages of colorectal cancer and in patients with nonresectable tumors. ${ }^{25,26}$

The level of VEGF was significantly higher in cancer patients than in the control group. This may be explained by the fact that VEGF plays an important role in angiogenesis involved in the growth and metastatic spread of solid tumors. ${ }^{27}$ Vascular endothelial growth factor levels were proportionally increased with the stage of cancer in colorectal cancer patients. These findings were consistent with results from other studies. ${ }^{28-30}$

The present study also showed that the elevated serum CRP levels were clearly associated with the stage of the disease in colorectal cancer patients (Tables 3, 4). In a study of 172 patients with colorectal cancer, the CRP levels were associated with larger tumor size, lymph node or liver metastasis and advanced modified Dukes stage. ${ }^{31}$ From the constructed ROC curve for the identification from the panel of tumor markers those with the greatest discriminatory power for the diagnosis of colorectal cancer, CEA was found to be the best tumor marker. These results are in agreement with that of Holmstrom and Coworkers $^{32}$ who found by estimating the probability of cancer with several tumor markers in 204 colorectal cancer patients using ROC curve, that the highest AUC was observed for CEA. The level of tumor markers that were receded to lower levels after surgical resection observed in this study has been also reported in previous studies on colorectal cancer patients. ${ }^{9,33-35}$

In the current study, all the colorectal cancer follow up group showed a marked decrease in the tumor markers except two patients. They showed a rise in the serum level of CEA, TPA, IL-6 and CRP. A diagnosis of recurrent disease was proved in both cases endoscopically and histopathologically. Similar studies showed that these markers were the most sensitive indices of recurrence..$^{20,33,36,37}$ Early detection of colorectal cancer relapse is an important factor in reducing cancer mortality. ${ }^{38}$

\section{CONCLUSION}

CEA, CA 19-9, CA 72-4, TPA, IL-6, VEGF and CRP are of considerable diagnostic, prognostic and follow up utility. ROC curve is used to enhance the diagnostic accuracy of the studied tumor markers.

\section{REFERENCES}

1. Al-Shamsi SR, Bener A, Al-Sharh M. Clinicopathological pattern of colorectal cancer in the United Arab Emirates. Saudi Med J 2003;24(5):518-522.

2. Vesna M. Risk factors for colorectal cancer. Arch Oncol 2004; 12(1): 45-49.

3. Cancer Registry Center (2009). Nineveh Health Authority, Mosul, Iraq (Personal Communication).

4. Schrohl A S, Mads H A, Fred S. Tumor markers from laboratory to clinical utility. Molecular and Cellular Proteomics 2003; 2: 378-387.

5. Kai S, Qian W, Xiao H. Establishment of multiplexed, microsphere-based flow cytometry assay for multiple human tumor markers. Acta Pharmacologica Sinica 2007; 28(12): 2011-2018.

6. Duffy MJ. CEA as a tumor marker for colorectal cancer: Is it clinically useful? Clin Chem 2002;47:625630.

7. Tohrn N, Hiroshi I, Terumits S. Circulating Sialyl Lewis, Sialyl Lewis and Sialyl tumor antigen in patients with diffuse type of gastric cancer. Acta Nakagoe 2003; 48:129-133.

8. Basuglo M, Kiziltunc A, Akay F. Increased serum CA 72-4 levels in patients with gastrointestinal carcinoma. Turkish J of Medical Sciences 1998;28: 259-263.

9. Concepcion P, Rodolfo A, Javier GT. An evaluation of tissue polypeptide antigen in the two bronchoalveolar lavage fractions of lung cancer patients. Jpn J Clin Oncol 2000; 30(5):215-220. 
10. Jiezhang C, Yu F H. IL-6 promotes carcinogenesis through multiple signal pathways. Digestive Disease Science 2009; 54: 1373-1374.

11. Harold F D. Vascular permeability factor/VEGF: A critical cytokine in tumor angiogenesis and a potential target for diagnosis and therapy. J of Clin Oncol 2002; 20(21): 4368-4380.

12. Tadahiro N, Emiko M, Ikuo T. Preoperative elevation of serum CRP as an independent prognostic indicator of colorectal cancer. Surgery Today 2008; 38:597-602.

13. Sorlie DE (ed). Medical biostatistics and epidemiology: Examination and board view. $1^{\text {st }}$ edition. Connecticut, Appleton and Lang. New York; 1995. p. 4788.

14. Ucar E, Semerrci E, Utsum H. Prognostic value of preoperative CEA, CA 19-9, CA 72-4 and AFP levels in gastric cancer. Advances in Therapy 2008;25(10):34-38. 15. Laszlo H, Fabio F, Cardin R. Tumor marker utility and prognostic relevance of cathepsin $B$, cathepsin $L$, urokinase-type plasminogen activator, plasminogen activator inhibitor type-1, CEA and CA 19-9 in colorectal cancer. BMC Cancer 2008; 8: 194.

16. Fiorella G, Mario R, Maurizio C, Ernisto M, Manfredo T. TAG-72 (CA 72-4) assay as a complementary serum tumor antigen to CEA in monitoring patients with colorectal cancer. Cancer 2006; 72(7): 2098-2106.

17. Meteoglu I, Meydan N, Erkus M. Id-1: regulator of EGFR and VEGF and potential target for colorectal cancer therapy. $\mathrm{J}$ of Experimental and Clinical Cancer Research 2008; 27: 118-123.

18. Kurt H, Johannes C K, Astrid S. Clinical value of determination of Urokinase-type Plasminogen Activator Antigen in plasma for detection of colorectal cancer: Comparison with circulating TAA CA 19-9 and CEA. Clinical research 1993; 53:1788-1793.

19. Alvarez J A, Marin J, Jover J M. Sensitivity of monoclonal antibodies to CEA, TPA, AFP, CA 50 and CA 19-9 in the diagnosis of colorectal carcinoma. Dis Colon Rectum1995; 38(5): 34-39.

20. Phlebani M, De Paoli M, Basso D. Serum tumor markers in colorectal cancer staging, grading and follow up. J of Surg Oncol 1998; 62(4): 239-244.

21. Tuncer I, Dulger H, Uygan I, Ozturk M. Comparison of serum cytokeratin-18, CEA and CA 19-9 levels in esophageal and gastric cancers. Eastern $\mathrm{J}$ of Med 2004; 9: $72-78$

22. Krauss H, Ignys I, Zygmunt K. Significance of the evaluation of the tissue proliferation specific marker (TPS) and the carcinoembryonic antigen in patients with ulcerative colitis and adenocarcinoma. Med Sci Monit.2002; 8(1) 48-51.

23. OH S, Kwen H, Yoo H. Preoperative levels of VEGF and IL-6 are associated with lymph node invasion and stage in gastric cancer. J Clin Oncol 2007; 25(18):67-75.
24. Hiroshi K, Yasohiro T, Masaharu H. IL-6 levels in colorectal cancer tissues. W J Sur 1998;22: 895-898.

25. Ashizawa T, Ryosuke O, Yoshiaki S. Study of IL-6 in the spread of colorectal cancer, the diagnostic significance. Acta Med Okayama 2006; 60(6): 325-330. 26. Groblewska M, Mroczko B, Wereszczynska S. Serum IL-6 and CRP levels in colorectal cancer patients. Clin Chem and Lab Medicine 2008; 46(10): 1423-1428.

27. Lai IR, Lee WJ, Huang MT. Comparison of serum CA 72-4, CEA, TPA, CA 19-9 and CA 125 levels in gastric cancer patients and correlation with recurrence. Hepatogastroenterology 2002; 49(46): 1157-1160.

28. Ilhan N, Ilhan N, Ilhan Y, Akbulut H, Kucuksu M. CReactive protein, IL-6, VEGF and oxidative metabolites in diagnosis of infection and staging in patients with gastric cancer. World J Gastroenterol 2004; 10(8): 11151120.

29. Srdjan N. Tumor markers in clinical oncology. Radiol Oncol 2004; 38(2):73-83.

30. Kobayashi $A$, Yamaguchi $T$, Ishihara $T$. Usefulness of plasma VEGF in the diagnosis of pancreatic cancer. Pancreas 2005; 31: 74-78.

31. Chung Y, Yuan C, Chang $Y$ F. Serum CRP correlates with survival in colorectal cancer but is not an independent prognostic indicator. Eur. $\mathrm{J}$ of Gastroenterology and Hepatology 2003; 15: 369-373.

32. Holmstrom M C, Louhimo J, Stenman U. Estimating the probability of cancer with several tumor markers in patients with colorectal diseases. Oncol 2004;66:269302.

33. Fernandes L C, Kim S B, Saad S S. Value of CEA and cytokeratins for the detection of recurrent disease following curative resection of colorectal cancer. WJG 2006; 12(24): 3891-3894.

34. Afify M, Sarry N, Hashem M, Essan T. Clinical significance of VEGF in Egyptian colorectal cancer patients. Inter J of Integrative Biology 2008; 4(2): 100107.

35. McMillan DC, Canna K, McArdle CS. Systemic inflammatory response predicts survival following curative resection of colorectal cancer. Br J Surg 2003; 90: 215-219.

36. Erlinger T P, Platz E A, Rifai N, Kathy J. C-reactive protein and the risk of incident colorectal cancer. JAMA 2004; 291(5): 585-590.

37. George L, Wu Z, Heinz J. Molecular prognostic markers in locally advanced colon cancer. Clinical Colorectal Cancer 2007; 6(10): 683-690.

38. Filiz A I, Ilkar S, Yavuz K, Karakas D O, Gulec B, Akin $M$ L. Persistent high postoperative CEA in colorectal cancer patients- is it important? Clinics 2009; 64(4):179. 